\title{
Metaphysics of Terrorism
}

\author{
Francis Etim \\ Department of Philosophy, University of Uyo, Uyo, Nigeria \\ Email: etimfrank@yahoo.com
}

How to cite this paper: Etim, F. (2018) Metaphysics of Terrorism. Advances in Applied Sociology, 8, 689-697. https://doi.org/10.4236/aasoci.2018.811041

Received: September 8, 2018 Accepted: November 27, 2018 Published: November 30, 2018

Copyright $\odot 2018$ by author and Scientific Research Publishing Inc. This work is licensed under the Creative Commons Attribution International License (CC BY 4.0).

http://creativecommons.org/licenses/by/4.0/

\begin{abstract}
Terrorism as the calculated use of violence or the threat to violence through the employment of intimidation and violence in order to attain goals that are political, religious or ideological in nature has taken a global dimension and at alarming frequency such that any curious mind cannot afford to over look. Its persistence despite global condemnation and effort at curbing it naturally evokes curiosity regarding its root cause(s). Scholars have tried to dig out its root causes ranging from poverty, lack of education, religious fanaticism, psychological malady and political reasons and so on. Solutions however differ based on its perceived causes. The question is why terrorism has continued unabated. This paper believes that since human actions are elicited by the idea of the good then terrorism as a human act is based on a disoriented perception of the good. This disoriented perception is premised on a more primordial cause, an ontological lacuna that can be tagged a "search for meaning" which the terrorist tries to fill by his terroristic act. This gives the terrorist a sense of fulfilment and relevance. The panacea, the paper submits, is in a metaphysical deconstruction and construction of the terrorist mind-set based on an ontology called affective humanism.
\end{abstract}

\section{Keywords}

Metaphysics, Existentialism, Terrorism, Affective Humanism

\section{Introduction}

No era has witnessed the rise of the phenomenon of terrorism than the 21st Century. Stories of terrorist activities rant the airwaves, fill pages of newspapers, and are topics for discussion in local and international fora. Examples abound ranging from the American twin tower attack on September 11, 2001, France bus explosion in 2017, the British Mosque attack in 2018 (Wikipedia), Boko Haram and Herd's men attacks in Nigeria since 2002 (Punch, 2018; Abubakar, 2018; Vanguard, May 18, 2014; Vanguard, 2018; Wikipedia, List of terrorist incidents; 
Okpala, Chijioke, \& Innocent, 2012; Eji, 2016; Faimau, 2013; Heryanto, 7 April, 2006). From the Wikipedia listing there is no doubt that every Country and Continent has a feeling of its effect directly or indirectly. Apart from few countries like Sudan and Israel where political reasons are adduced as the root cause of terrorism, the upsurge of religious related terroristic activities like Boko Harom, Isis, al-Qaeda, Taliban, Azzam and so on inclined many to isolate religion and religious fanaticism as its sole root cause. This must have informed the definition of terrorism as "the opinions and actions that create social panic, endanger public safety, infringe upon personal rights and property, or coerce state organs and international organizations by means of violence, destruction and intimidation in order to achieve their political and ideological purposes". This underscores the basic difference between terrorism and a revolution which may not necessarily involve violence and intimidation, targeted at the civilian. A terrorist then is regarded as a radical who employs terror as a political weapon, often using religion as a cover for terrorist activities; one who carries radical ideas or opinions. As a radical, he is regarded as an extremist or an ultra conservative whose opinion is far beyond the norm. The terrorist's extremity or conservatism is rooted in an ontology beyond the manifestations of religious rascality or fanaticism. This may explain why solutions so far proffered based on perceived political and religious extremities have not reduced the phenomenon of terrorism in the 21st Century. The exacerbated terroristic activities therefore, raise some fundamental questions regarding the primordial cause of terrorism and naturally arouse in the mind of any thinking person the curiosity for the raison d'etre of terrorism. Deductively, therefore, this paper is persuaded to believe that the unabatedness of terrorism despite all efforts is a pointer to a more rooted cause than the usual perceived causes. Based on an existential analysis of man as a being-in-the-world, this paper adduces the primordial cause as being an existential lacuna created by the terrorist's "search for meaning" using Victor Frankl's terminology. The unearthing and examination of this existential lacuna then constitutes the crux of this article, the Metaphysics of Terrorism. To facilitate this search, it is germane to analyze the nature of man based on existentialist perspective because according to Grene $(1957,1995)$ "it is the nature of man to ask the all important question, what it is to be? This question to him, is both existential and metaphysical"; hence, the necessity to carry out an existential analysis of the nature of man.

\section{The Nature of Man: The Existentialist's Perspective}

According to the Existentialists, the existence of man precedes essence. This means that man's nature is determined not by any given essence but by his existentiality. This philosophy which began in the nineteenth Century "focuses on the nature and meaning of human existence as understood from the subjective standpoint of the subject. It repudiates the notion of a fixed nature man as espoused by the ancient and scholastic period but believes that man continually 
creates the self though his choice and actions" (Lawhead, 2002). So, in essence who man is, is the outcome of his choices and actions and not what nature had made of him. For an existentialist like Heidegger (1987), man's existentiality is essentially "being-with" which implies "being-in-the-world" with co-humans (da-sein) and other non-humans (seinde) without whom man does not realize himself. In the world, man relates with other existents in the mood of care which constitutes of three moments-existentiality, facticity and falleness. Existentiality connotes the reality of man as a bundle of possibilities. It denotes the fact that man is always ahead of himself, his immediate environment and circumstances towards the power to be. In other words, man is constantly out beyond himself; throwing himself towards what discloses it as a possibility" (King, 1964). Facticity has to do with man's past. It denotes all in human existence that could be described as "given" and not dependable on choice, e.g. talents, height, race, sex, intelligent quotient (I.Q). For Heidegger, facticity expresses the fact that man has been thrown into the world which is not his world without consultation. Man only becomes aware of his presence in the world like a bird hatched and abandoned. Despite the fact of throwness, man can still realize himself because all facticity includes being-able-to-be. Falleness is understood within man's relationship and responsibility. This connotes man's existential fact as a-being-in-the-world of things and co-human beings. Within this existential reality called care, there is a tendency of man to either become overbearingly exploitative of fellow humans, subsumed in the crowd or becomes absorbed in the world of technology and science. This invariably results in inauthentic existence. On the other hand, living responsibly in the world by consciously taking control of one's life in the midst of other humans and things and treating others humans "as ones who exist in the same way as himself" (Heidegger, 1987; Brainswanger, 1968) constitutes authentic existence. Within man's existence in the world, certain moods like anxiety, conscience, curiosity and understanding play decisive roles in re-ordering man to the part of authentic existence in case of any drift.

\section{Metaphysics of Terrorism}

Metaphysics here connotes "the underlying principles of action, subject or existent; the primordial cause, the first principle and assumptions underlying an enquiry or a philosophical theory" ("Metaphysics", Wikipedia, Online). In the words of Kamal (2008), it has to do with the essence of thing, the "to be", "what is it to be", the "being" of existence or phenomenon. This paper at this juncture seeks to discover the primordial (metaphysical) reason, the essence and cause of terrorism.

In analysing and discussing the essence of terrorism, Kamal (2008) made allusion to Hegel in The Phenomenon of the Mind as being the first in the history of modern philosophy to give a philosophical bent to terrorism by attributing it to "the search or need of recognition". For Hegel, an individual desire for recognition acts as a necessary impulse in history. It provides objective certainty for 
one's own independence, as the self needs the other for recognition. While arguing against Hegel's position, Kamal (2008) maintains that if this was the essence of terrorism, then the terrorist would not be killing the other since he needs the existence of the other for this recognition just as in a slave and master relationship. Kamal, therefore, argues for annihilation as the essence of terrorism. In his words:

...the essence of terrorism is "annihilation". The aim of terrorism is not to subjugate but to annihilate the other. Annihilation is the negation of the independence of the other as well as total destruction of its existence. It is an action through which the other is reduced to a "thing" but transformed from the state of existence to non existence. The recognized self reduces the recognizing self to a mere object, while a terrorist self reduces this other to "nothing".

No doubt, "need for recognition" and "annihilation" could be regarded as constitutive of terroristic act but this may be more as consequences than primordial causes. What then could be regarded as the essence of terrorism calls for a deeper analysis of the cause of human action. Human action both metaphysically and morally is intrinsically teleological. The telos then provides the motivation for the action. Thinkers in various fields have tried to discover this driving force (motivating factors) in man. For instance, psychologists like A. Maslow sees human actions are motivated by certain needs in a pyramidal fashion: psychological, safety, love and belonging, esteem, self actualization and self transcendence. The first constitutes what he refers to as "deficiency need" which includes basic necessities like water, air, food clothing and shelter. After this, safety needs like personal security, financial security, health and wellbeing, etc, then become a source of concern. With the satisfaction of safety needs, interpersonal feelings of belonging and love become an issue; self esteem and self respect follows and finally the yearning for self actualization and self transcendence. For A. Adler (1938), human action is elicited by the "will to power"; Freud (1937) in his psychoanalysis sees "will to pleasure as the driving force of human action while Victor Frankl (2006) subscribes to "will to meaning" as accountable for the driving force of man's action.

For philosophers like Socrates, human action is elicited by knowledge and this constitutes knowledge as virtue. Aristotle subscribed to the fact that it is the idea of the good that motivates human actions. A perverted idea of the good will definitely lead one to wrong and bad actions. For Hamlyn (1971) it is self awareness which involves:

a conception of oneself as a certain kind of person, the picture people have of themselves, the attribution to oneself and others of various characteristics and the presentation of oneself to others and the place of other people's attitude in one's picture of oneself

The terrorist then would be acting with a pervert idea of self which is suscep- 
tible to any manner of bad actions. In the words of E. Esen (1982):

This pervasive tendency is not just a feeling of honest doubt about oneself... It is not even a question of uncertainty about one's reflective standing compared with the rest... It is rather related to the very serious issue of the way one sees oneself or oneself concept negatively. Such a person or nature may be consciously engaged in self rejection, which is both pathological and disastrous.

Definitely, actions exuding from such a person will not be motivated by good intention. That is why there is always a flight from reason and reality to the externalization of the perceived self in the victim. Having lived in a world of dehumanized perception of self, the terrorist sees nothing wrong in dehumanising their victim. It is within this world of perceived-self that he realizes his "meaning to life" since every man lives in search of self realization by making meaning of his life by every choice and decision he makes. Since this meaning must be realized within the world as a theatre of action, then encounter with fellow humans and non-human existents become imperative for its realization. This thought of the worldishness of human action could be gleaned from Frankl's thought that "the true meaning of life is to be discovered in the world rather than within own psyche as though it were a closed system" (Frankl, Quotes, Online). The terroristic activities then provide the locus not only for the terrorist's realization of self, but satisfy his yearning for both meaning and relevance to life.

Leaning on this consideration and analysis, this paper considers "the search for meaning" as being the essence of terrorism. Living within the perverted world of self, the terrorist sees the other as avenue for expressing and realizing himself. He achieves this by reducing "the other", who should be naturally regarded as co-dasein and equal, mentally and physically, to "nothing", an "it" (seinde), which therefore can be exploited for his self actualization. Since nothing but dasein and sein exist, the dasein can be exploited to the terrorist's advantage. In line with the existentialist position, the phenomenal manifestation of the terrorist action, be it in intimidation, killing, maiming and so on, are elicited by a primordial cause of "the search for meaning". The search for meaning can be adduced as the motif and explanation for his terroristic actions.

\section{Necessity for Deconstruction and Re-Construction}

To Chukwuemeka Nze's (1998) mind, "what a man is should elicit from him some expectations (emphasis mine) and definite relationships with other beings and in particular, with his fellow human beings" since, metaphysically, agree sequitur see (a being acts according to his nature). The existential reality of the terrorist then is certainly questionable, since his actions are contrary to any expectation of him as a-being-in the-world that necessarily needs others to realize himself positively. The terrorist seems to be living in a fantalistic world of dislocated actualized self which consequently translates into a perverted perception of himself and the world around him. The terrorist's world and his interpretation 
of reality ensue from his mind construct which earnestly seeks to realize and to find meaning to his life. Within this adroit search for meaning and given his mind set, he sees nothing wrong with his terroristic activities. He then sets out to realize himself within his world as informed by his ontological and epistemological construct.

Any change in this construct requires an apprehension or awareness which only a deconstruction to reconstruct a positive selfhood and world could achieve. To deconstruct here connotes the departure from the old pervasive perception of self to a new and positive realization of self. The braking down of the old mind-set of the terrorist enables him come to the realization of the benefit of the necessity of "the other" in his search for meaning. Deconstruction alone will not provide the necessary departure from the old way, so there is also a need to imbue a new mind set, a re-orientation that will create the definite and required impact in the terrorist. This is what this paper refers to as re-construction.

This indeed is an adroit task since the terrorist perception of self and his world is already fixated and precipitated by so many factors ranging from poor home training, parental neglects, bad peer group influence, poverty, poor education, societal stigma, and so on. Within this situation, economic empowerment and military attack may not be solutions as in the case of Boko Haram and Niger Delta Avengers. It could even be impetus for regrouping or trigger more negative impulses from the terrorist.

According to Toynbee and Ikeda (1989), since humans are not animals, "it has a spiritual task which is to overcome his egoism by expanding his ego until it becomes coextensive with the ultimate reality, for which it is in truth inseparable and the ultimate reality is what human being is". For Nze (1998), this involves calculating the amount of goodness in the consequences that will follow from each alternative act open to man. Since our response and choice then depend on our perception of the good, the task here is to re-orientate the terrorist to think humanly and to act according to his beingness as man since as noted by Frankl "between stimulus and response, there is a space. In that space is our power to choose our response" (Quotes, Online). The capacity to choose and act correctly and considerately then requires a natural disposition (habitus) to do good since nemo dat quod non habet (one cannot give what he has not.

Inculcating such disposition to think and act with good intention in a terrorist is as tasking as the mouse trying to bell the cat. The first target should then be would-be and intending terrorists. According to Maslow (1954), one cannot choose wisely for a life unless "he dares to list to himself, his own self, at each moment of life and to say calmly, no, I don't like such and such". Such conscious decision-taking is only possible in a mind that is empowered with positive perception of self and the world. Such empowerment is possible with and through didactic education suffused with critical thinking and altruistic thought we refer to here as affective humanism. So affective humanism then becomes a "meta-motivation" (using Maslow's phrase) of action. 
Affective humanism as a philosophy of action is premised on the African ontology of communalism and harmonious monism. African ontology hinges on a dualistic universe that is integrative and complementary. Both worlds are peopled with existents, visible and invisible respectively; hierarchically placed but complementary in existentiality. Every existent then lives in complementarity, harmoniously and integratively. Within this placement, every man needs another to live meaningfully and authentically. Since the world is the theatre of action for the realization of trueself, then the other persons and things are equally important. Affective humanism does not consist in loving others as one would love himself but involves what both Maslow and Frankl call "auto-transcendence of self-transcendence". Self-transcendence denotes:

The fact that being human always points, and is directed, to something or someone, other than oneself be it a meaning to fulfil or another to encounter. The more one forgets himself-by giving himself to a cause to serve or another person to love the more human he is and the more he actualizes himself (Frankl, Quotes, Online).

No one can love except he transcends himself; and Frankl described love as: ....the only way to grasp another human being in the innermost core of his personality. No one can become fully aware of the very essence of another human being unless he loves him. By his love, he is enabled to see the essential traits and features in the beloved person; and even more, he sees that which is potential in him, which is not yet actualized but yet ought to be actualized (Quotes, Online).

That is why Frankl sees love as the ultimate goal to which man can aspire and that the salvation of man is through love and in love. Since every education involve some kind of indoctrination, indoctrinating the would-be terrorist(s) with the ethos and principle of affective humanism will re-orientate his mind towards a positive meaning of live which his daily choices and encounter with fellow humans and things provide veritable avenues.

\section{Conclusion}

The position of this paper has been that terrorism as a human action is precipitated by factors beside what may be visible and this account for its endemic and frequent nature. Ontologically, since all actions are elicited by the perception of the good and since the terrorist sees nothing wrong with his action and even derive pleasure from it then there is something definitely wrong with the terrorist's idea of the good which needs a deconstruction. Since such deconstruction will be tasking, if not unrealizable in a terrorist, then targeting intending terrorist; though didactic education suffused with the ethos of affective humanism; will go a long way to achieve the aim of stopping terrorism in the future as no new member would be willing to join them. The choice of affective humanism which is anchored on African ontology of harmonious monism and complementarity is 
a way of underscoring the fact that terrorism is unAfrican and anti-African and its ideals and therefore, should be repudiated by the Africans. There is a great necessity for reinventing veritable cultural values and proper family upbringing in line with the principle that says "train a child in a way that he should go then when he grows up, he will not depart from it". Though cultural values differ and what family hold in esteem cannot be universalized, there are basic requirement for healthy and human relationship which this paper may not have discussed because of the ambient of the paper as a philosophical discuss. This other aspects, I hope, could be further explored for the betterment of man and healthy human relationship.

\section{Conflicts of Interest}

The author declares no conflicts of interest regarding the publication of this paper.

\section{References}

Abubakar, Y. (2018) Boko Haram: The Most Challenges Internal Security Threat in Nigeria since after the Civil War. https://leadership.ng/2018/09/27/reappressing-nigeria-ascounter-terrorism-effort

Adler, A. (1938). Social Interest. London: Faber and Faber.

Brainswanger, L. (1968). Heidegger's Analysis of Existence and Its Meaning for Psychiatry. In L. Lindney Hall et al. (Eds.), Theories of Personality (254-263). New York: John Wilby.

Eji, E. (2016). Rethinking Nigerians Counter-Terrorism Strategy.

Esen, A. J. (1982). Ibibio Profile. Calabar: Paico Press.

Faimau, G. (2013). Socio Cultural Construction of Recognition: The Discursive Representation of Islam and Muslims in the British Christian News Media. Cambridge: Cambridge Schooling Publishing.

Frankl, V. (2006). Man's Search for Meaning. New York: Bacon Press

Frankl, V. Quotes. https://www.goodreads.com/author/quotes/2782.Victor_E_Frankl

Freud, S. (1937). The Ego and the Mecahnism of Defense. New York: Norton.

Grene, M. (1957). Martin Heidegger. In P. Edwards (Ed.), Encyclopedia of Philosopshy (450-600). New York: Macmillan Press.

Grene, M. (1995). Martin Heidegger. In P. Edwards (Ed.), Encyclopedia of Philosopshy (450-600). New York: Macmillan Press.

Hamlyn, J. (1971). Theory of Knowledge. London: Macmillan Press.

Heidegger, M. (1987). Being and Time. Macquerrie and Robinson Edwards (Trans.). Great Britain: Camelot Press.

Kamal, M. (2008). The Meaning of Terrorism: A Philosophical Inquiry. National Centre of Excellence for Islamic Studies. NCEIS Research Papers, Australia: Groffith University, The University of Malbourne, University of Western Sydney. https://arts.unimelbredu.au/data/NCEIS_Research_papaer_Vol.1

King, M. (1964). Heidegger's Philosophy. Oxford: Aldreen Press.

Lawhead, F. W. (2002). Voyage of Discovery: A Historical Introduction to Philosophy. New York: Thomson Advantage Books. 
Maslow, A. (1954). Motivation and Personality. New York: Harper Press.

Metaphysics. https://wikipedia.org/wiki/metaphysics

Nze, C. B. (1998). Accountability. In J. O. Oguejiofor (Ed.), Africa, Philosophy and Public Affairs (pp. 51-57). Enugu: Delta Publication.

Okpala, A., Chijioke, U. S., \& Innocent, I. O. (2012). Activities of Boko Haram and Insucurity Question in Nigeria. Arabian Journal of Business and Management Review, 1, 79-99. http://www.arabianjbmr,com/pdfs/Om.../6.pdf

Punch (2018). Editorial. Herdsmen Terrorism: Buhari at It Again.

https://punchng.com/herders-terrorism-buhari-at-it-again

Toynbee, A., \& Ikeda, D. (1989). Choose Life Us. London: Oxford University Press.

Vanguard (2018). Agreeing with Stakeholders on Our Victory against Terrorism. Viewpoint.

https://www.vanguardngo.com/2018/ageeing-wth-stakeholders-on-our-victory-against -terrorism

Wikipedia. List of Terrorist Incidents. https://en.wikipedia.org/wiki/list_of_terrorist_incidents 